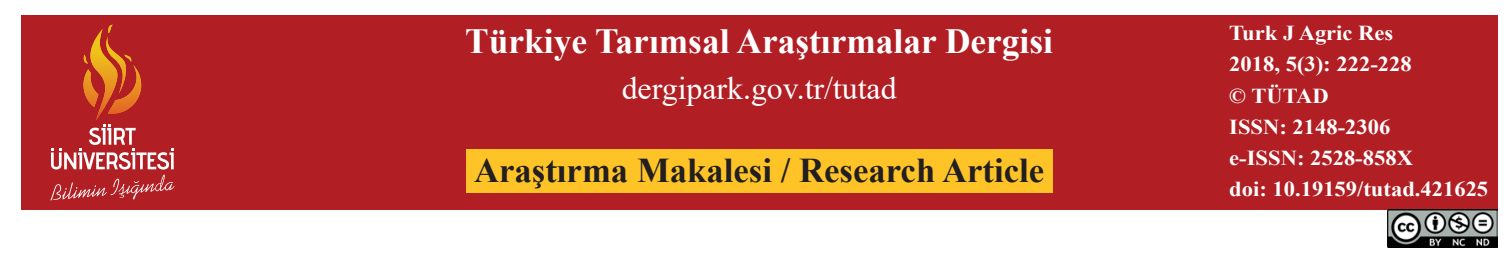

\title{
Bazı Yonca (Medicago sativa L.) Genotipleri Arasındaki Varyasyonun Kümeleme ve Temel Bileșen Analizi Metodu ile Belirlenmesi*
}

\author{
Mehmet ÖTEN ${ }^{1 * *}$, Sebahattin ALBAYRAK ${ }^{2}$ \\ ${ }^{\prime}$ Batı Akdeniz Tarımsal Araştırma Enstitüsü Müdürlüğ̈̈, Tarla Bitkileri Bölümü, Aksu-Antalya, TÜRKIYYE \\ ${ }^{2}$ Ondokuz Mayls Üniversitesi, Bafra Meslek Yüksekokulu, Bitkisel ve Hayvansal Üretim Bölümü, Bafra-Samsun, TÜRKIYYE
}

\begin{tabular}{|c|c|}
\hline Geliş Tarihi/Received: 07.05 .2018 & Kabul Tarihi/Accepted: 26.09 .2018 \\
\hline \multicolumn{2}{|l|}{ ORCID ID (Yazar sirasina göre / by author order) } \\
\hline (1D)orcid.org/0000-0001-8299-2805 Dorcid.org/0000-0002-4247-7064 & \\
\hline
\end{tabular}

Öz: Bu çalışmanın amacı; yonca ileri ıslah programlarında kullanılmak üzere, 26 adet yonca populasyonunu, 21 özellik açısından değerlendirip, morfolojik olarak akrabalık dereceleri NTSYS 2.1 paket programı kullanılarak korelasyon matriksi ile kümeleme/tartısız aritmetik grup ortalamaları (UPGMA) metotlarına göre belirlenmesidir. Araştırmada tarla denemesi 2013 ve 2014 yıllarında Batı Akdeniz Tarımsal Araştırma Enstitüsü Müdürlüğü deneme alanında yürütülmüştür. Yapılan kümeleme analizi sonucunda; hatlar \% 50 ile \% 98 arasında benzerlik göstermiștir. Genotiplerin ortalama benzerlik katsayısı $\mathrm{r}=0.50$ olup, buna göre genotipler 2 ana grup altında 5 alt gruba ayrılmıştır. Temel bileşen analizi sonucu ise genotiplere ait toplam varyasyonun \% 84.33'ünü tanımlayan 6 adet temel bileşen ekseni elde edilmiştir.

Anahtar Kelimeler: Yonca, kümeleme, temel bileșen, akrabalık derecesi

\section{Determination of Variation Between Some Alfalfa (Medicago sativa L.) Genotypes by Principal Component and Clustering Analysis}

\begin{abstract}
The aim of this study is to evaluate 26 alfalfa population in terms of 21 characters and to determine morphology of kinship degrees by using NTSYS 2.1 statistical software based correlation matrix and unweigted pair group method arithmetic average (UPGMA). The study carried in trial area of Bat1 Akdeniz Agricultural Research Institute in 2013-2014. As a result of the clustering analysis; correlation coefficients among pairs ranged from $50 \%$ to $98 \%$. The average similarity coefficient of the genotypes was $\mathrm{r}=0.50$ and five subgroup were detected under the two main groups. Six basic component axes were obtained that defining $84.33 \%$ of the total variation of genotypes.
\end{abstract}

Keywords: Alfalfa, cluster, principal component, relationship

\section{Giriș}

Hayvanların kaba yem gereksinimlerinin kısa vadede karşılanması için, tarla tarımı içinde yetiştirilen yem bitkilerine büyük önem verilmesi gerekmektedir (Karaköy, 2001). Türkiye'de, çok yıllık baklagil yem bitkisi olarak yonca (Medicago sativa L.) kuru ve sulu şartlarda yetiştirilen önemli bir yem bitkisidir. Yem bitkileri tarımının geliştirilmesi açısından, yonca ıslah çalışmalarının arttırılması, ekolojik şartlara uyum gösterebilen yüksek verimli çeşitlerin geliştirilmesi büyük önem arz etmektedir. Islah çalışmalarında ilk basamak, doğal kaynakların değerlendirilmesidir ve bu aşamada birçok değişkene ait gözlemler alınmaktadır. Elde edilen veriler varyans analizi ile analiz edilmekte ve yorumlanmaktadır. Ancak son y1llarda birden fazla değişkenin birlikte analiz

\footnotetext{
“: Bu çalışma; Süleyman Demirel Üniversitesi, Fen Bilimleri Enstitüsü’nde yürütülen Doktora Tez çalışmasının bir bölümünü içermektedir.
} 
edilebildiği teknikler ortaya çıkmıştır (Özdamar, 2004). Çoklu değişken analizleri (multivariate) olarak adlandırılan kümeleme ve temel bileşen analizi gibi yöntemler, mevcut varyasyonun ortaya konmasında yaygın olarak kullanılmaktadır (Hair ve ark., 1995; Tan, 2005).

Kümeleme analizi; grupları kesin olarak bilinmeyen, birimleri, değişkenleri birbiriyle benzer alt kümelere (grup, sınıf) ayırmaya yardımcı olan çok değişkenli istatistiksel analiz yöntemlerinden birisidir. Kümeleme analizinin temel amac1 birimleri sahip oldukları karakteristik özellikleri temel alarak gruplandırmaktır (Özdamar, 2004). Çok değişkenli istatistik tekniklerinden biri olan kümeleme analizi, istatistik sonuç çıkarmaya dayanmayan tanımlayıcı özelliği olan bir analizdir.

Temel bileşen analizinde ise, çok boyutlu alan içinde genotipler arasındaki ilişkiyi en iyi temsil edecek bir eksen ya da eksenler dizisi üzerindeki izdüşümlerinin görüntülenmesi temeline dayanmaktadır. Ana bileşenler çevresinde dağılan örneklerin varyansları her bir bileşen için ayrı ayrı hesaplanmaktadır. Bunlara da öz değer (eigen değeri) adı verilmektedir. Öz değer değerlerinin 1'den büyük bileşenler için toplam varyans oranları ve kümülatif (eklemeli) varyans değerleri belirlenmektedir (Ferriol ve ark., 2003; Mohammadi ve Prasanna, 2003; Karaağaç, 2006).

$\mathrm{Bu}$ çalışma ile 26 adet yonca genotipine ait morfolojik gözlem değerleri kullanılarak, kümeleme analizi ve temel bileşen analizi metotları vasıtası ile morfolojik olarak akrabalıklarını ortaya konulması amaçlanmıştır.

\section{Materyal ve Yöntem}

Araştırmada tarla denemesi Batı Akdeniz Tarımsal Araştırma Enstitüsü deneme alanında, tesadüf blokları deneme desenine göre üç tekrarlamalı olarak yürütülmüştür. Araştırmada, deneme 2012 yılında tesis edilmiş olup ilk yıl kültürel işlemler ve çiçeklenme döneminde yapılan biçimler haricinde hiçbir gözlem alınmamış; denemeye esas veriler, 2013-2014 yıllarında alınmaya başlamıştır. Araştırmanın yürütüldüğü topraklar; milli kil bünyeye sahip, tuzsuz, çok yüksek kireçli, kuvvetli alkali ve organik madde içeriği düşük topraklardır (Tablo 1).

Tablo 1. Araştırma alanı topraklarının bazı fiziksel ve kimyasal özellikleri

\begin{tabular}{lc}
\hline Toprak özelliği & Değeri \\
\hline $\mathrm{pH}$ & 8.6 \\
Kireç, \% & 24.8 \\
EC, mikromhos & 197 \\
Kum, \% & 15 \\
Kil, \% & 43 \\
Mil, \% & 42 \\
Organik madde, \% & 1.88 \\
\hline
\end{tabular}

Tarla denemelerinin yürütüldüğü yıllar ile uzun yıllara ait bazı iklim verileri incelendiğinde; ilk yıl en yüksek oransal nem Mart ayında tespit edilirken, ikinci yıl gözlemlerin alındığı Eylül ayı sonuna kadar en yüksek oransal nem Mayıs ayında gerçekleşmiştir. Birinci yıl yıllık yağış miktarı 727 mm iken, gözlem alınan 10 aya ait yağış toplamı $606 \mathrm{~mm}$ olmuştur. Her iki yılda da yağış miktarı uzun yıllar ortalamasından düşüktür (Tablo 2).

Tablo 1'deki toprak analiz sonuçlarına göre; 21/11/2012 tarihinde yapılan klonla ekimden önce, dekara $16 \mathrm{~kg}$ hesabiyla triple süper fosfat (TSP, $\%$ 43-44 $\mathrm{P}_{2} \mathrm{O}_{5}$ ) ve dekara $8 \mathrm{~kg}$ hesabiyla amonyum sülfat $(\% 23 \mathrm{~N})$ her parsele homojen olacak şekilde uygulanmıştır. Deneme süresince Mayıs ayından Ekim ayına kadar çiçeklenme öncesinde ve biçimden hemen sonra sulama yapılmıştır.

Tablo 2. Tarla denemelerinin yürütüldüğ̈ 2013-2014 ve uzun yıllara (1961-2014) ait bazı iklim verileri (Anonim, 2014)

\begin{tabular}{|c|c|c|c|c|c|c|c|c|c|}
\hline \multirow[b]{2}{*}{ Aylar } & \multicolumn{3}{|c|}{2013} & \multicolumn{3}{|c|}{2014} & \multicolumn{3}{|c|}{ Uzun yillar } \\
\hline & $\begin{array}{l}\text { Yağ1ş } \\
(\mathrm{mm})\end{array}$ & $\begin{array}{c}\text { Nispi nem } \\
(\%)\end{array}$ & $\begin{array}{c}\text { Sicaklik } \\
\left({ }^{\circ} \mathrm{C}\right)\end{array}$ & $\begin{array}{l}\text { Yağ1ş } \\
(\mathrm{mm})\end{array}$ & $\begin{array}{c}\text { Nispi nem } \\
(\%)\end{array}$ & $\begin{array}{l}\text { Sicaklik } \\
\left({ }^{\circ} \mathrm{C}\right)\end{array}$ & $\begin{array}{l}\text { Yağ1Ş } \\
(\mathrm{mm})\end{array}$ & $\begin{array}{l}\text { Nispi nem } \\
(\%)\end{array}$ & $\begin{array}{c}\text { Sicaklik } \\
\left({ }^{\circ} \mathrm{C}\right)\end{array}$ \\
\hline Ocak & 203 & 74.4 & 10.2 & 224 & 68 & 8.65 & 224.9 & 9.8 & 15 \\
\hline Şubat & 59 & 74.9 & 12.1 & 112 & 64.6 & 8.2 & 156.3 & 10.4 & 15.5 \\
\hline Mart & 19 & 69.7 & 13.3 & 66 & 57.5 & 12.15 & 96.2 & 12.7 & 18 \\
\hline Nisan & 34 & 67.1 & 17.7 & 51 & 62.2 & 16.9 & 58.3 & 16.1 & 21.3 \\
\hline May1s & 56 & 66 & 22.5 & 64 & 72 & 20.9 & 31.8 & 20.5 & 25.6 \\
\hline Haziran & 0 & 61.6 & 25.4 & 4 & 63.4 & 27 & 7.9 & 25.4 & 30.9 \\
\hline Temmuz & 16 & 57.8 & 28 & 0 & 61.3 & 29.8 & 3 & 28.4 & 34.1 \\
\hline Ağustos & 0 & 57.6 & 28.7 & 0 & 59.6 & 28.65 & 2.4 & 28.2 & 34.2 \\
\hline Eylül & 19 & 58 & 24.7 & 20 & 60.4 & 25.11 & 13.7 & 24.7 & 31.2 \\
\hline Ekim & 89 & 53.4 & 18.1 & 65 & 57.7 & 19.87 & 78.8 & 20 & 26.6 \\
\hline Kasim & 179 & 71.5 & 15.9 & - & - & - & 137.1 & 14.9 & 21.1 \\
\hline Aralık & 53 & 58 & 9.56 & - & - & - & 259.4 & 11.3 & 16.6 \\
\hline Y1ll1k & 727 & - & - & 606 & - & - & 1069.8 & - & - \\
\hline
\end{tabular}


Araştırmada; ilkbahar, yaz, sonbahar ve k1ş dönemlerinde bitkinin kaplama alanı (1-dar; 9-geniş), biçimden sonra yeniden büyüme hızı (biçimden 2 hafta sonra; 1 çok yavaş, 9-çok hızlı), yayılma alanı (\% olarak toprak yüzeyini kaplama alanı), büyüme şekli (1-dik, 9-yatık), rizomlu bitkilerin varlığı (1-yok, 9-çok fazla) (Altınok ve ark., 2011; Albayrak ve ark., 2014), doğal bitki boyu $(\mathrm{cm})$, ana sap uzunluğu $(\mathrm{cm})$, yaprak büyüklüğü (1-küçük, 9-büyük), kök tacinda dal sayısı (adet), kök tacının yapısı (1- dar bir alanda çok fazla ince dal, 2-bir ana dal ve birçok küçük dal oluşmuş), çiçek rengi, çiçeklenme başlangıcına kadar geçen gün sayısı (gün) gözlemleri ile birlikte; ilk biçim kuru madde verimi (kg), yıllık kuru madde verimi (kg), ilk biçim kuru madde verimi/yıllık kuru madde verimi oranı $(\%)$, ham protein (HP) oranı $(\%)$, asit deterjanda çözünmeyen lif oranı (ADF, $\%$ ), nötral deterjanda çözünmeyen lif oranı (NDF, \%) gibi verim ve kalite özellikler incelenmiştir.

Elde edilen veriler, United States Department of Agriculture, Agricultural Research Service (USDA, ARS), Ulusal Genetik Kaynakları Programı (Anonymous, 2012) ve Prosperi ve ark. (2006)'nın yonca için belirtilen kriterlerine ve skala değerlerine göre yapılmıştır.

Kümeleme analizi, Tartısız Aritmetik Grup Ortalamaları (Unweighted Pair-Group Method Algorithm (UPGMA) metodu yardımıyla, akrabalık düzeylerini gösteren dendogramlar oluşturularak gerçekleştirilmiştir (Sneath ve Sokal, 1973; Mohammadi ve Prasanna, 2003). Temel bileşen analizi yapmak için ise Numerikal Taksonomi Multivaryasyon Analiz yöntemiyle NTSYSpc versiyon 2.01 bilgisayar paket programı kullanılmıştır (Rohlf, 2005).

\section{Bulgular ve Tartışma}

\subsection{Morfolojik, verim ve kalite özellikleri}

Rizomlu bitkilerin varlığı, kök tacının yapısı ve çiçek rengi hariç, bütün genotiplerde geniş bir varyasyon tespit edilmiştir. Söz konusu üç gözlem de ise tüm genotiplerde aynı değerler tespit edilmiştir. İlkbaharda bitkinin kaplama alanı puanı 5.7-9.0, yazın bitkinin kaplama alanı puanı 4.3-8.0, sonbaharda bitkinini kaplama alanı puanı 3.3-6.2, kışın bitkinin kaplama alanı puanı 3.2-5.0, biçimden sonra yeniden büyüme hızı puanı 4.5-7.8, yayılma alanı 65-100, büyüme şekli puanı 1.0-3.2, doğal bitki boyu 89.0-57.9 cm, ana sap uzunluğu 97.8$73.1 \mathrm{~cm}$, yaprak büyüklüğü puanı 4.3-7.7, kök tacında dal sayısı 27.3-71.0 adet, çiçeklenme başlangıcına kadar geçen gün sayıs1 193.0-205.3 gün, ilk biçim kuru madde verimi $62.1-190.7 \mathrm{~kg}$, y1llık kuru madde verimi 949.5-331.4 kg, ilk biçim kuru madde verimi/yıllık kuru madde verimi oranı
$\%$ 0.17-0.27, HP oranı \% 12.8-17.9, ADF oranı $\%$ 34.5-39.5, NDF oranı \% 44.5-50.0 olarak belirlenmiştir (Tablo 3).

\subsection{Kümeleme analizi}

Araştırmada incelenen genotipler \% 50 ile \% 98 arasında benzerlik göstermiștir. Kümeleme analizi sonucunda, genotiplerin ortalama benzerlik katsayıs1 $r=0.50$ olup, bu ortalamaya göre genotipler 2 ana grup altında 5 alt gruba ayrılmaktadır. Birinci alt grupta, Gazipaşa1, Kemer1, Alanya1, Aksu2, Finike2, Kepez1, Kaş1, Döşemealtı1, Demre1 ve Konyaaltı1 genotipleri; ikinci alt grupta, Serik2, Konyaalt12, Aksu1, Finike1, Demre2, Kepez2 ve Kumluca2 genotipleri; üçüncü grupta, Gazipaşa2, Manavgat2, Serik1, Kemer2 ve Kaş2 genotipleri; dördüncü alt grupta, Alanya2, Manavgat1 ve Döşemealtı2 ve beşinci grupta ise, Kumlucal genotipi yer almıştır. Morfolojik gözlem değerleri ile yapılan analiz sonucunda, Aksu2 ve Finike2 genotipleri \% 93 oranında benzerlik gösterirken, genotipler arasında en uzak olanlar ise Gazipaşa1 ve Kumlucal olarak bulunmuştur (Şekil 1).

Aygün ve ark. (2009) domuz ayrığı (Dactylis glomerata L.)'1nda, Bilmez ve Söğüt (2015) susam (Sesamum indicum L.)'da, Balkaya ve ark. (2005) lahana (Brassica oleracea var. acephala)'da ve Öten ve ark. (2017) ise mürdümük (Lathyrus sativus L.)'te morfolojik ve diğer tarımsal gözlemler ile kümeleme analizi yapılmışlar ve farklı grupların oluştuğunu tespit etmişlerdir. Annicchiarico (2006) ve Benabderrahim ve ark. (2009) çalışmamızla benzer şekilde yoncada morfolojik özelliklere göre kümeleme analizi gerçekleştirmiş ve farklı gruplar tespit etmiştir.

\subsection{Temel bileşen analizi (TBA)}

İncelenen özellikler yönünden öz değerleri 1 'den büyük ve birbirinden bağımsız 6 adet TBA ekseni elde edilmiştir. Bu TBA eksenlerinin öz değerleri 1.00-9.61 arasında değişmekte olup, genotiplere ait toplam varyasyonun \% 84.33'ünü tanımlamaktadır (Tablo 4).

Ele alınan özelliklerin temel bileşenlerdeki ağırlık değerleri incelendiğinde; TBA1 ekseninde yer alan özellikler, biçimden sonra yeniden büyüme hızı ve yayılma alanı özellikleri varyasyonun $\%$ 45.79'unu temsil ettiği görülmektedir. Çalışmada, TBA2 ekseninde yer alan özellikler, ilk biçim kuru madde verimi, yıllık kuru madde verimi, ilk biçim kuru madde verimi/yıllık kuru madde verimi oranı ve ADF oranı varyasyonun \% 14.74 ünü belirleyen önemli özelliklerdir. Varyansın \% 7.41'ini temsil eden TBA3 ekseninde ise ana sap uzunluğu, kök tacında dal sayısı, 


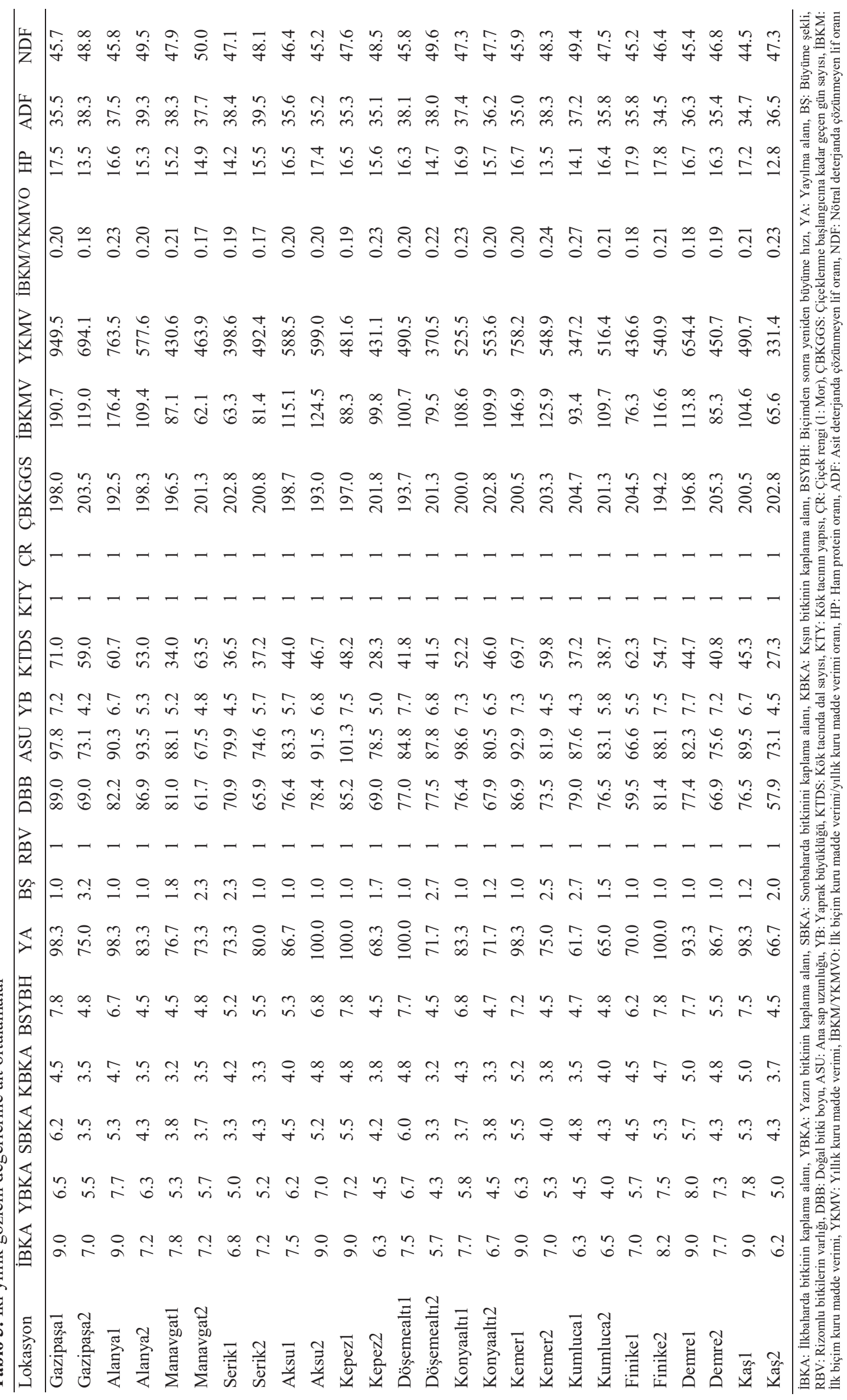




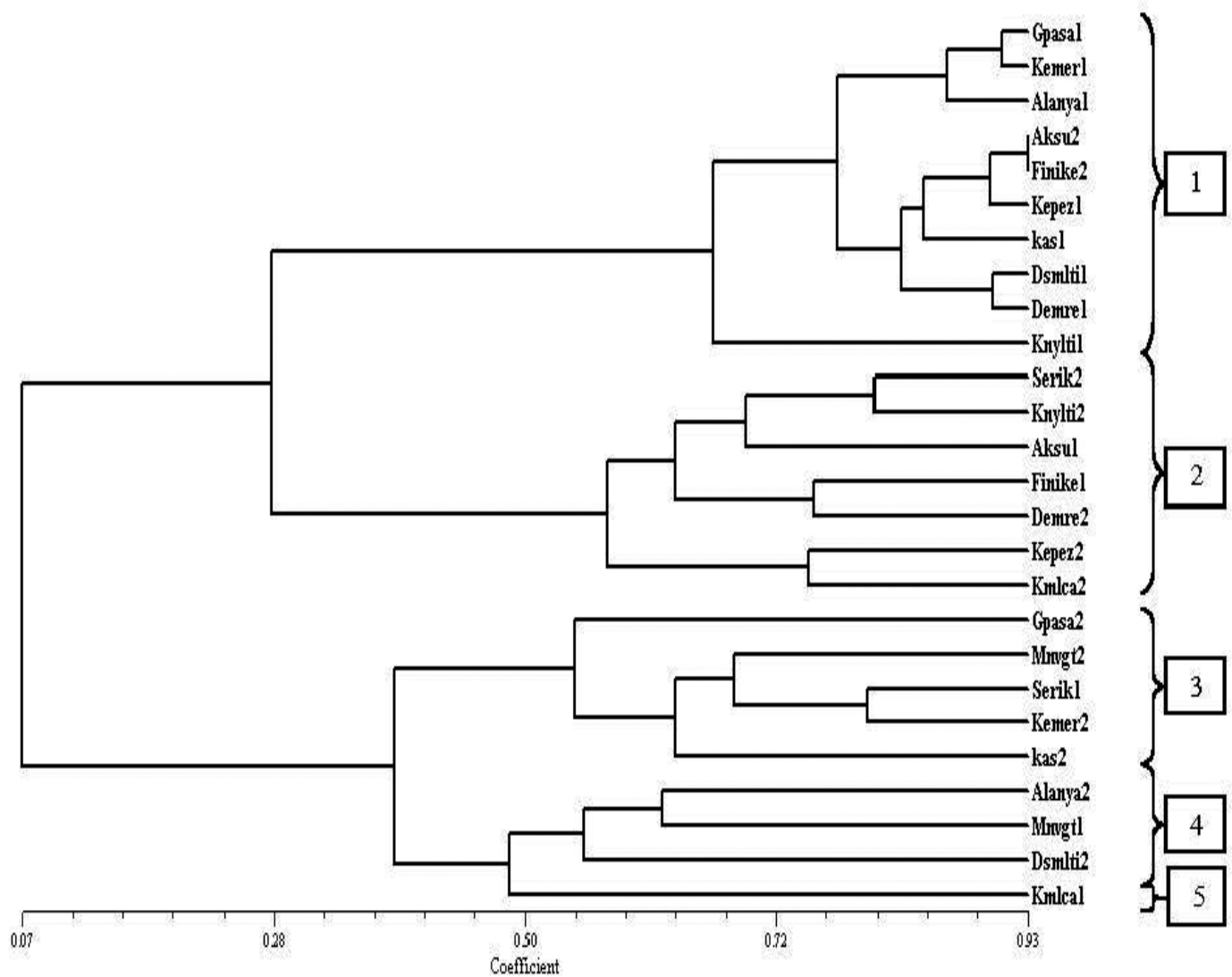

Şekil 1. M. sativa L. genotiplerinin UPGMA'ya göre kümeleme dendogramı

Tablo 4. M. sativa L. genotiplerinin temel bileşen analizi sonuçları

\begin{tabular}{|c|c|c|c|c|c|c|}
\hline Öz değeri & 9.61 & 3.10 & 1.56 & 1.28 & 1.16 & 1.00 \\
\hline Varyans (\%) & 45.79 & 14.74 & 7.41 & 6.10 & 5.53 & 4.76 \\
\hline Toplam varyans (\%) & 45.79 & 60.53 & 67.94 & 74.04 & 79.57 & 84.33 \\
\hline Özellikler & TBA1 & TBA2 & TBA3 & TBA4 & TBA5 & TBA6 \\
\hline İlkbaharda bitkinin kaplama alanı & 0.30 & 0.04 & 0.05 & 0.07 & 0.14 & -0.00 \\
\hline Yazın bitkinin kaplama alanı & 0.28 & -0.06 & -0.02 & 0.23 & 0.23 & 0.00 \\
\hline Sonbaharda bitkinini kaplama alanı & 0.27 & -0.04 & 0.04 & -0.11 & 0.12 & 0.00 \\
\hline Kışın bitkinin kaplama alanı & 0.27 & -0.15 & 0.14 & 0.10 & 0.16 & -0.00 \\
\hline Biçimden sonra yeniden büyüme hızı & 0.30 & -0.07 & 0.03 & 0.05 & 0.12 & 0.00 \\
\hline Yayılma alanı & 0.31 & 0.02 & -0.10 & 0.09 & 0.03 & -0.00 \\
\hline Büyüme şekli & -0.24 & 0.25 & -0.01 & 0.19 & 0.15 & 0.00 \\
\hline Rizomlu bitkilerin varllğ 1 & -0.00 & -0.00 & 0.00 & 0.00 & -0.00 & 1.00 \\
\hline Doğal bitki boyu & 0.21 & 0.28 & -0.27 & -0.35 & -0.09 & 0.00 \\
\hline Ana sap uzunluğu & 0.20 & 0.22 & -0.34 & -0.40 & -0.01 & 0.00 \\
\hline Yaprak büyüklüğü & 0.26 & -0.14 & -0.10 & -0.12 & -0.24 & -0.00 \\
\hline Kök tacında dal sayısı & 0.15 & 0.29 & 0.33 & 0.32 & -0.24 & -0.00 \\
\hline Kök tacının yapısı & 0.11 & 0.21 & -0.13 & 0.20 & 0.53 & 0.00 \\
\hline Çiçek rengi & 0.16 & 0.21 & -0.27 & 0.41 & 0.05 & -0.00 \\
\hline Çiçeklenme başlangıcına kadar geçen gün sayısı & -0.23 & -0.03 & 0.33 & 0.04 & 0.06 & -0.00 \\
\hline İlk biçim kuru madde verimi & 0.12 & 0.40 & 0.42 & -0.22 & -0.01 & 0.00 \\
\hline Yıllık kuru madde verimi & 0.19 & 0.31 & 0.36 & 0.08 & -0.23 & -0.00 \\
\hline İlk biçim kuru madde verimi/yıllık kuru madde verimi oranı & -0.13 & 0.31 & 0.17 & -0.37 & 0.46 & 0.00 \\
\hline Ham protein & 0.25 & -0.19 & 0.14 & -0.17 & -0.23 & 0.00 \\
\hline Asit deterjanda çözünm & -0.02 & 0.40 & -0.23 & 0.24 & -0.33 & -0.00 \\
\hline Nötral deterjanda çözünmeyen lif & -0.24 & 0.21 & -0.24 & -0.01 & -0.12 & 0.00 \\
\hline
\end{tabular}


çiçeklenme başlangıcına kadar geçen gün sayısı, ilk biçim kuru madde verimi ve yillık kuru madde verimi özellikleri yer almakta; TBA4 ekseni ise varyasyonun \% 6.10’unu temsil eden doğal bitki boyu, ana sap uzunluğu, kök tacında dal sayısı, çiçek rengi ve yıllık kuru madde verimi özelliklerden oluşmaktadır. Analiz sonucuna göre, TBA5 ekseninde yer alan özellikler kök tacının yap1s1, yıllık kuru madde verimi ve ADF oranı özellikleri varyasyonun \% 5.53'ünü temsil ettiği görülmektedir. TBA6 ekseninde yer alan rizomlu bitkilerin varlığ1 gözlem değeri varyasyonun \% 4.76`sını belirleyen önemli özelliktir.

Temel bileşen analizinin etkin kullanılabilmesi ve doğru yorumlanabilmesi için toplam varyasyonun ilk iki veya üç bileşen oranının $\% 25$ 'ten büyük olması gerekir (Mohammadi ve Prasanna, 2003). Ayrica analizin yorumlanmasında temel bileşen sayısı belirlenirken toplam varyansın 2/3'ü esas alınır. Populasyonun toplam varyansı olan \% 84.33'ün 2/3 olan \% 56.22 değeri esas alındığında, 2 TBA ekseni bu değeri karşılamaktadır. Çalışmada TBA eksenlerinde incelenen morfolojik özellikler bakımından bileşenlerdeki ağırlık değerleri 0.3 ve üzerinde olduğu takdirde önemli ağırlığa sahip oldukları kabul edilmektedir (Gözen, 2008).

Buna göre; genotiplerin morfolojik olarak tanımlanmasında yeterli görülen ilk iki eksenden TBA1 ekseninde ilkbaharda bitkinin kaplama alanı, biçimden sonra yeniden büyüme hızı ve yayılma alanı özellikleri; TBA2 ekseninde ise, ilk biçim kuru madde verimi, yıllık kuru madde verimi, ilk biçim kuru madde verimi/yıllık kuru madde verimi oranı ve ADF özellikleri, genotipleri morfolojik olarak tanımlamada yeterli bulunmuştur.

Yoncada yaptıkları araştırmalarının sonucundaki temel bileşen analizi neticesinde; Jenczewski ve ark. (1999) toplam varyasyonun \% 75'ini, Annicchiarico (2006) \% 35'ini ve Tucak ve ark. (2009) \% 89.02'ini tanımladığını bildirmişlerdir. Çalışmalar arasındaki benzerlik ve farklılıklar, kullanılan genotiplerden ve coğrafi farklılıklardan kaynaklandığı düşünülmektedir. Nitekim, Dias ve ark. (2007) ve Sardana ve ark. (2007) benzer şekilde morfo-agronomik özellikler kullanarak Temel Bileşen analizi yaptıkları çalışmalarında, coğrafi farklılık ve genetik çeşitliliğin büyük önem arz ettiğini bildirmişlerdir.

\section{Sonuçlar}

Araştırma sonucunda elde edilen morfolojik, verim ve kalite özelliklerinden rizomlu bitkilerin varlığı, kök tacının yapısı ve çiçek rengi özellikleri arasında herhangi bir varyasyon belirlenemezken, diğer özellikler arasında geniş bir varyasyon tespit edilmiştir. Esas olarak yonca genotiplerinin morfolojik olarak akrabalık derecelerini tespit ederek, ileri 1slah programlarında kullanılmak üzere seçiminin yapılması amacıyla yürütülen bu çalışma sonucunda; Aksu2 ve Finike2 genotipleri \%93 oranında benzerlik gösterirken, genotipler arasında en uzak olanlar ise Gazipaşa-1 ve Kumluca-1 olarak bulunmuştur. Genotiplerin morfolojik olarak tanımlanmasında yeterli görülen TBA1 ekseninde ilkbaharda bitkinin kaplama alanı, biçimden sonra yeniden büyüme hızı ve yayılma alanı özellikleri, TBA2 ekseninde ise, ilk biçim kuru madde verimi, yıllık kuru madde verimi, ilk biçim kuru madde verimi/yıllık kuru madde verimi oranı ve asit deterjan fiber özellikleri genotipleri morfolojik olarak tanımlamada yeterli bulunmuştur.

\section{Teşekkür}

Çalışma, Süleyman Demirel Üniversitesi (SDÜ) Bilimsel Araştırma Projeleri (BAP) Yönetim Birimi Başkanlığı tarafından "SDÜ-BAP-3190-D1-12" numaralı proje ile desteklenmiştir.

\section{Kaynaklar}

Albayrak, S., Türk, M., Sevimay, C.S., Kazaz, S., Tong, M., 2014. Göller yöresinde adi yonca (Medicago sativa L.) populasyonlarının toplanması ve karakterizasyon çalışmaları. Sonuç Raporu, TUBİTAK, Proje No: $110 \mathrm{O} 257,74 \mathrm{~s}$.

Altınok, S., Türk., M, Erol, T., 2011. Ankara ili doğal vejetasyonunda bulunan yabani yonca (Medicago sativa L.) populasyonlarının toplanması ve karakterizasyon çalışmaları ile mera tipi yonca hatlarının belirlenmesi. Sonuç Raporu, TUBİTAK, Proje No: $108 \mathrm{O} 634,115 \mathrm{~s}$.

Annicchiarico, P., 2006. Diversity, genetic structure, distinctness and agronomic value of Italian lucerne (Medicago sativa L.) landraces. Euphytica, 148(3): 269-282.

Anonim, 2014. T.C. Gida Tarım ve Hayvancılık Bakanlığı, Tarım İşletmeleri Genel Müdürlüğü Boztepe Tarım İșletmesi Müdürlüğü, Meteoroloji İstasyonu Verileri, Antalya.

Anonymous, 2012. United States Department of Agriculture (USDA), Agricultural Research Service, National Plant Germplasm System, (http://www.arsgrin.gov/npgs/descriptors/alfalfa), (Erişim tarihi: 13.07.2012).

Aygün, C., Çakal, Ş., Kara, A., 2009. Characterization of some coksfoot (Dactylis glomerata L.) lines from the natural rangelands of Eastern Anatolia. Biological Diversity and Conservation, 2(2): 57-64.

Balkaya, A., Yanmaz, R., Kar, H., Apaydın, A., 2005. Morphological characterisation of white head cabbage (Brassica oleraceae var. capitata subvar. alba) genotypes in Turkey. New Zeland Journal of Crop and Horticultural Science, 33(4): 1-9. 
Benabderrahim, M.A., Mansour, H., Ali, F., 2009. Diversity of lucerne (Medicago sativa L.) populations in south Tunisia. Pakistan Journal of Botany, 41(6): 2851-2861.

Bilmez, A., Söğüt, T., 2015. Türkiye'nin farklı bölgelerinden sağlanan susam (Sesamum indicum L.) populasyonlarının agro-morfolojik özellikler bakımından karşılaştııılması. 11. Tarla Bitkileri Kongresi, 7-10 Eylül, Çanakkale, s. 240-241.

Dias, P.M.B., Julier, B., Sampoux, J.P., Barre, P., Dall'Agnol, M., 2007. Genetic diversity in red clover (Trifolium pratense L.) revealed by morphological and microsatellite (SSR) markers. Euphytica, 160(2): 189-205.

Ferriol, M., Picó, B., Nuez, F., 2003. Genetic diversity of a germplasm collection of Cucurbita pepo using SRAP and AFLP markers. Heoretical and Applied Genetics, 107: 271-282.

Gözen, V., 2008. Hiyarda (Cucumis sativus L.) örtü alt1 yetiştiriciliğine uygun hibrit çeşit ıslahında morfolojik karakterizasyon, hibrit kombinasyonları ile hibrit tohum verim ve kalitesinin belirlenmesi. Doktora tezi, Ankara Üniversitesi Fen Bilimleri Enstitüsü, Ankara.

Hair, J.R., Anderson, R.E., Tatham, R.L., Black, W.C., 1995. Multivariate Data Analysis with Readings. 4th Edition, Prentice-Hall, Englewood Cliffs (NJ).

Jenczewski, E., Prosperi, J.M., Ronfort, J., 1999. Evidence for gene flow between wild and cultivated medicago sativa (Leguminosae) based on allozyme markers and quantitative traits. American Journal of Botany, 86(5): 677-687.

Karaağaç, O., 2006. Bafra kırmızı biber (Capsicum annuum var. conoides Mill.) gen kaynaklarının karakterizasyonu ve değerlendirilmesi. Yüksek lisans tezi, Ondokuz Mayıs Üniversitesi Fen Bilimleri Enstitüsü, Samsun.

Karaköy, K., 2001. Çukurova koşullarında yonca (Medicago sativa L.) ile farklı oranlardaki domuz ayrığ1 (Dactylis glomerata L.) ve kılçıksız brom (Bromus inermis L.) karışımlarının ot verimi ve verimle ilgili özelliklere etkisi üzerinde bir araștırma. Yüksek lisans tezi, Çukurova Üniversitesi Fen Bilimleri Enstitüsü, Adana.

Mohammadi, S.A., Prasanna, B.M., 2003. Analysis of genetic diversity in crop plants salient statistical tools and considerations. Crop Science, 43(4): 1235-1248.

Öten, M., Çeçen, S., Erdurmuş, C., 2017. Antalya doğal florasından toplanan bazı mürdümük (Lathyrus sativus L.) hatlarının verim özelliklerinin belirlenmesi. Ege Üniversitesi Ziraat Fakültesi Dergisi, 54(1): 17-26.

Özdamar, K., 2004. Paket Programlar ile İstatiksel Veri Analizi (Çok Değișkenli Analizler). 5. Bask1, Kaan Kitapevi.

Prosperi, J.M., Jenczewski, E., Angevain, M., Ronfort, J., 2006. Morhological and agronomic diversity of wild genetic resources of Medicago sativa L. collected in Spain. Genetic Resources and Crop Evaluation, 53(4): 843-856

Rohlf, F.J., 2005. NTSYS-pc: Numerical Taxonomy and Multivarite Analysis System. Version 2.2, User Guide, Exeter Software, New York.

Sardana, S., Mahajan, R.K., Gautam, N.K., Ram, B., 2007. Genetic variability in pea (Pisum sativum L.) germplasm for utilization. SABRAO Journal of Breeding and Genetics, 39(1): 31-41.

Sneath, P.H.A., Sokal, R.R., 1973. Numerical Taxonomy. W.H. Freman Co., San Francisco, USA.

Tan, Ş., 2005. Bitki Islahında İstatistik ve Genetik Metotlar. Ege Tarımsal Araştırma Enstitüsü Müdürlüğü Yayın No: 121, Menemen/İzmir, s.129145.

Tucak, M., Popović, S., Čupić, T., Šimić, G., Gantner, R., Meglič, V., 2009. Evaluation of alfalfa germplasm collection by multivariate analysis based on phenotypic traits. Romanian Agricultural Research, 26: 47-52. 